\title{
„Żyłem z wieszczem tym za młodu, jak brat z bratem..." - towarzyskie i poetyckie związki Januarego Poźniaka i Wincentego Pola
}

\begin{abstract}
Przed Januarym P[oźniakiem] wylałem dzisiaj całą mą duszę; czuł razem ze mną i jeden człowiek, który mnie chciał rozumieć i zrozumiał. Boże, wszytkiegoś mi odmówił! Wszędzie mnie prześladujesz, daj mi przynajmniej przyjaciela, któryby pomógł dźwigać ten ciężar, pod którym odwaga, siła i rozum upada ${ }^{1}$,
\end{abstract}

wyznawał w czerwcu $1828 \mathrm{r}$. Wincenty Pol o bliskim mu już od lat sanoczaninie. January Poźniak (1809-1883) był synem Grzegorza Feliksa Marka de Krziwkowicz Poźniaka herbu Przestrzał i Marianny Katarzyny Bobrowicz Sas-Jaworskiej. Dzieciństwo spędził w rodzinnym majątku Nowotaniec, gimnazjum ukończył we Lwowie w 1826 r., a potem rozpoczął studia na tamtejszym Wydziale Filozoficznym. Po zakończeniu kursu wstępnego wybrał prawo na Wydziale Prawa i Umiejętności Politycznych Uniwersytetu Franciszkańskiego. Za sprawą Jana Kantego Podoleckiego, u którego w Rzepiedzi był częstym gościem², zaprzyjaźnił się z Wincentym Polem. Tej znajomości z kolei Poźniak zawdzięczał częste pobyty w Mostkach pod Lwowem u wuja Pola - Józefa Ziętkiewicza ${ }^{3}$. Wizyty

\footnotetext{
* Dr hab. Jolanta Klimek-Grądzka - Katedra Języka Polskiego, Katolicki Uniwersytet Lubelski Jana Pawła II; e-mail: jolanta.klimek@kul.pl.

${ }^{1}$ K. Estreicher, Wincenty Pol - jego młodość i otoczenie (1807-1832), Lwów 1882, s. 100.

2 Tamże, s. 73.

3 "Józef Ziętkiewicz był pierwotnie kupcem bławatnym i właścicielem kamienicy we Lwowie, lecz już w r. 1814 czy 1815 zwinął sklep i przeniósł się do Mostek. Gorący patryota, gościnny, z wylanem sercem dla każdego, podejmował po staropolsku całą rodzinę swoją, zubożałych przytulał do siebie najserdeczniej”, tamże, s. 39.
} 
motywowane były nie tylko spotkaniami z pomieszkującym tam Polem, ale również z Agnieszką Ziętkiewiczówną, która ostatecznie w 1838 r. została żoną Poźniaka ${ }^{4}$.

Działalność poetycka była pragnieniem Januarego Poźniaka, któremu się z zapałem poświęcił i z którym wiązał swoją przyszłość. Traktował ją niezwykle poważnie, dbał o warsztat; po latach wspominał:

[...] studiowałem: dzieje naszego narodu; dzieła znakomitszych naszych poetów i prozaików z nowszych i z Zygmuntowskich czasów; pieśni gminne, nasze i Serbów; z obcych mistrzów poezyi, Goethego, Schillera, Szekspira, Byrona, Dantego i Tassa; z niemieckich prozaików, dzieła Wilhelma i Fryderyka Schleglów; a i klasyków rzymskich - w oryginale; greckich zaś - w tłómaczeniach, czytywałem z zajęciem. Pisywałem pieśni, które się moim młodym kolegom podobały i powziąłem był zamiar, wszystkie dni mego żywota, poświęcić jedynie pracy na niwie naszego piśmiennictwa ${ }^{5}$.

Te kompetencje potwierdza Estreicher, któremu Poźniak pomagał przy biografii Wincenty Pol - jego młodość i otoczenie (1807-1832):

Wierzyć chcę i wierzyć muszę świadkowi codziennemu czynności Pola, Januaremu Poźniakowi. Twierdzi on, że nietylko znał dokładnie klasyków, historyę powszechną i ojczyste dzieje, lecz gruntownie badał systemata filozofii niemieckiej ${ }^{6}$.

Bibliograf bez ogródek pisze, iż to pod wpływem starszego przyjaciela Poźniak „Zaczął w 16. roku życia, na utrapienie kolegów swoich, układać wiersze”, a „wierszowanie szło [mu] gładko"s. Poźniakowe wierszowanie - w XIX-wiecznym tego słowa rozumieniu ${ }^{9}$ - to przede wszystkim operowanie dokładnymi rymami, głównie niegramatycznymi, co podnosi ich wartość, np.: sosna - rosna (Sokót), róży - wróży (Na dolinie), pieści - treści (Przemienię się), choć nie brakuje gra-

${ }^{4}$ Druga córka Ziętkiewicza, „Amalia, wierna tradycyi rodziny Ziętkiewiczów, miłowała poezyą, wielbiła Wincentego. Popróbowała uprawy niwy poetyckiej, a próba wydała wdzięczne owoce. Jakże zgrabny jest wierszyk jej pod tytułem Nie kochaj w roku 1878 Januaremu Poźniakowi udzielony", tamże, s. 41. O Agnieszce Estreicher wspomina: „Agnieszka, pieszczona Agnes, Jagusia, Jadzia, bardzo muzykalna, wspólnie z Anielą dobierały muzykę do piosnek Wincentego Pola i Januarego Poźniaka”, tamże, s. 44. Biogram Januarego Poźniaka opracowany na podstawie: Poźniak January, w: Polski słownik biograficzny, t. 28, Wrocław-Warszawa 1984, s. 311-312 i Poezja Januarego, „Tygodnik Sanocki" 2008, 51/52.

${ }^{5}$ J. Poźniak, Pieśni..., s. IV.

${ }^{6}$ K. Estreicher, Wincenty Pol..., s. 109.

7 Tamże, s. 71.

8 Tamże, s. 70.

9 wierszować 'pisać lub mówić wierszem, do wiersza; układać wiersze, rymować', SWar, t. 7, s. 586. 
matycznych, utartych współbrzmień typu krzak - tak (Przemienię się), noc - moc (Regestrowi), kraj - maj (Stłum-że serce bole).

Sam Poźniak potwierdza towarzyszącą mu od najwcześniejszych utworów motywację „piszę dla kolegów”, por. Do milczącej gęśli:

Lecz jak szum wody, jęk wichru przelata,

Przebrzmi ten akord rzewny bez wieści, bez chwały;

Gdyż ja nie wieszczem; nie śpiewam dla świata,

Tylko druchom, gdy w piersi uczucia wezbrały;

Bo wieszcz, co z bratem orłem wiatry goni,

Znużony, na wyniosłych szczytach skał usiada,

Jeśli w twe struny dla świata zadzwoni:

Płyną tony rozkoszne, jak łabędzi stada -

Wieszczowi ziemia i niebiosa wtórzą ${ }^{10}$.

Marzenia o życiu spędzonym na działalności literackiej nie ziściły się, Poźniak z żalem po latach wyznawał:

Wypadki nieprzewidziane, spowodowały obdłużenie majętności ziemskiej moich rodziców po nad jej wartość i taką ruinę ich mienia: że już podczas uniwersyteckich studiów prawniczych, zmuszony byłem do zarobkowania w kancelaryi adwokata. (...) Dusza rwała się do zajęć literackich; bo serce je umiłowało, a konieczność, stworzona zupełnym brakiem zasobów materyjalnych, a nadto stosunkami rodzinnymi, nakazywała, rzucić literaturę i powszedniego chleba szukać w powszednim zarobkowania zawodzie. W służbie sądowej przebyłem lat czterdzieści - ciężkie to dla mnie były lata. Zadość uczynienie pod każdym względem obowiązkom sędziowskim, co mi sumienie i wzgląd na dobro kraju nakazywały, wymagało tyle czasu, że pracom literackim, które zupełnie porzucić nie było mi możebnem, one bowiem były dla mnie tym kwieciem, co barwiło twarde żywota mego koleje, mogłem poświęcać zaledwie kilkanaście godzin w miesiącu, a i to najczęściej, uszczuplając liczbę godzin na odpoczynek przeznaczonych; to też praca ma literacka z okresu mej służby sądowej, skąpo wydała owoce ${ }^{11}$.

Nie on jeden porzucić musiał marzenia o działalności poetyckiej. To doświadczenie łączyło go m.in. z Karolem Estreicherem, który we wstępie do biografii Pola, zwracając się wprost do Januarego Poźniaka, pisze:

Tyś Rusin, więc nic dziwnego, że z uporem trzymałeś się drużyny literackiej, jam zarwał coś uporu twego, i obadwaj wytrwaliśmy. Nie opuściliśmy rąk — nie zaparliśmy się powo-

${ }^{10}$ J. Poźniak, Pieśni..., s. 2.

11 Tamże, s. IV-V. 
łania. Gdyśmy jednak wówczas ucierali się z trudnościami, nie przewidywałeś tego, że za lat wiele, iż dzisiaj, kiedy w odstawkę poszedłeś, a ja mam się ku odstawce, przyjdzie nam znowu na współkę i to według skłonności naszej, ku literackiej zawrócić się niwie ${ }^{12}$

Do bywającej w Mostkach „drużyny literackiej” Pola i Poźniaka należeli również, poza Estreicherem, m.in. Faustyn Szołajski, Stanisław Niezabitowski, Ludwik Nabielak, Wacław Zaleski, Prawosław Kaubek, Leopold Neumann, Stanisław Piłat czy Bazyli Lewicki ${ }^{13}$ - wzajemnie się motywujący i inspirujący do działalności poetyckiej i naukowej. Ten okres życia Poźniaka przypomniany został w jego prasowych nekrologach, np.: „Serdeczna przyjaźń łączyła skromnego pieśniarza z całą ówczesną kolonją literacką, która społeczeństwu, nielitościwie niemczonemu przez absolutyzm austrjacki, odkrywała skarby polskiego ducha”'14, „był to rodzaj galicyjskiego Sturm- und Drankperiode, w której ś.p. Poźniak, jakkolwiek nie obrał sobie literatury za zawód wyłączny, brał udział z młodzieńczym entuzjazmem. Ścisła przyjaźń łączyła go ze wszystkimi niemal pionierami nowego życia i ruchu na polu umysłowem"15.

Polowi i Poźniakowi nieobce były również działania na gruncie teatralnym - podczas studiów we Lwowie współpracowali przy inscenizacji Krakowiaków i Górali Kamińskiego w przekładzie Franciszka Polla: „rękopis zaginął, tylko kilka ustępów zapamiętał jeszcze January Poźniak, który wraz z Wincentym Polem, zajmował się urządzeniem tej reprezentacji”" ${ }^{\prime \prime}$. Wspólnie także podróżowali do miejsc ważnych dla przeszłości Polski, w tym śladami Jana III Sobieskiego ${ }^{17}$.

Poźniak publikować zaczął dopiero u schyłku życia. W 1883 r. tuż przed jego śmiercią, ukazały się zbiory Pierwiosnki z przed lat przeszło pięćdziesięciu i Pieśni z lat młodych i pieśni starca. W drugim z wymienionych tomów Poźniak zgromadził utwory $\mathrm{z}$ lat 1828-1882, wśród nich dedykowane lub poświęcone Wincentemu Polowi i jemu najbliższym.

\section{Związki towarzyskie}

Sonet z 1829 r. to bezpośredni - za pomocą apostrofy mój Wincenty! - zwrot do W. Pola. J. Poźniak - podówczas 20 -letni - snuje rozważania na temat przyszłości dwóch orłów i dwóch dębów:

12 K. Estreicher, Wincenty Pol..., s. 1.

13 Tamże, passim.

14 [Kronika] „Dziennik Polski”, 1883, nr 83.

15 [Kronika] „Dziennik Lwowski”, 1883, nr 81

${ }_{16}$ K. Estreicher, Wincenty Pol..., s. 345-346.

17 A. Pol, Estyma Wincentego Pola do króla Jana III Sobieskiego, „Komunikaty MazurskoWarmińskie”, 2001, nr 1, s. 68. 


\section{[...] Uściśnie dęba dąb ponury,}

Choć z nich jesień obedrze wszystek liść zielony;

A gdy burza przeminie, rozejdą się chmury,

To orły na rodzinne przylecą zagony...

I nas wkrótce rozłączą dziwnych losów burze,

Ale po latach wielu, wierzaj, że wywróżę,

Powrócimy w te drogie sercom naszym ściany;

A chociaż wstąpiemy w jesienne koleje,

Czas dni wiośniane z życia, jak liść z dębów zwieje,

Tak się uściśniem starcy jak dzisiaj młodziany ${ }^{18}$.

Zgodnie z przewidywaniem poety gimnazjalni przyjaciele wkrótce mieli się rozstać - Pol w 1830 r. rozpoczął pracę na Uniwersytecie Wileńskim jako wykładowca języka niemieckiego, natomiast Poźniak „wstąpił [...] ukończywszy uniwersytet, po przebytej kilkumiesięcznej z samym sobą walce, $\mathrm{z}$ rozgoryczonem i ze zbolałem wskutek walki tej sercem, w służbę rządową do sądownictwa"19.

Wincenty Pol na kartach poezji Poźniaka określany jest mianami wskazującymi na bliskość poetów - pojawiają się przyjaciel i zbliżone semantycznie leksemy $b r a t^{20}$ i $d r u h^{21}$, a także formy pokrewne, np.:

Bracie! Gdyśmy byli młodzi;
Tak uczucia w piersiach wrzały,
Jak wód fale przy powodzi,
Gdy uderzą prądem w skały ${ }^{22}$,

Bo nasza przyjaźń trwałą,

jakby słup z granitu ${ }^{23}$,

Hej, mój druhu! ${ }^{24}$

${ }_{18}$ J. Poźniak, Pieśni..., s. 34.

19 Tamże, s. IV. Por.: „Gdy roku 1829 Poźniak wstąpił na praktykę do adwokata, miał stałą płacę i to, co klienci dawali na kancelaryę, szło w podział między dependentów. Tym dochodem żyli dwaj przyjaciele, bo Wincentemu płaca od matki wystarczyć nie mogła. Wspólnie pracowali, a do złożenia ostatecznych egzaminów głównie Poźniak Wincentemu dopomógł. Tej obopólnej łączności świadectwem są tłumaczone przez nich w r. 1826 wiersze z Franciszka Polla. Poźniak przetłumaczył Wieczór, a Wincenty przełożył Kolory”, K. Estreicher, Wincenty Pol..., s. 71.

${ }^{20}$ brat 9. ' $=$ przyjaciel od serca; $\mathrm{z}$ którym się poufale żyje, poufalec', SWil, s. 108.

${ }^{21}$ druh 'przyjaciel, towarzysz, wspólnik', SWil, s. 256.

22 J. Poźniak, Pieśni..., s. 276.

${ }^{23}$ Tamże, s. 127.

${ }^{24}$ Tamże, s. 371. 
Także Wincenty Pol opisuje swoją przyjaźń z Poźniakiem - w dzienniku z czerwca 1829 r. pisze:

P. Januarego (Poźniaka) muszę codzień więcej kochać, sądzę, że się nie zawiodę; oddam mu moje serce, nigdy on wprawdzie nie mówi o przyjaźni, lecz to jest właśnie dobrze. On zdaje się być dla mnie stworzony a ja tyle razy zawiedziony i zdradzony od przyjaciół, chcę jeszcze raz tylko zawierzyć, może się przecie znajdzie dusza, która się pozna na tem sercu. Gdyby tylko takim był dla mnie jak Longsz(any) o ile byłbym bogatszym! Lepszych przyjaciół mieć nie można ${ }^{25}$.

Użyte przez Pola leksemy i związki frazeologiczne z pola tematycznego MIŁOŚĆ: kochać, zawierzyć, oddać komuś serce, być dla kogośstworzonym, jednoznacznie pokazują serdeczność związków łączących poetów.

January Poźniak dokumentował w swoich wierszach wydarzenia z życia przyjaciela-poety. Najlepszym przykładem jest Wiersz na pożegnanie Wincentego Pola, w którego podtytule zawarto uwagę nawiasową z objaśnieniem kontekstu: (odjeżdżającego do Wilna $z$ tym zamiarem, by objąć tam katedrę niemieckiego języka i niemieckiej literatury) z 1 sierpnia 1830 r. Dodajmy, że Poźniak miał udział w tym zatrudnieniu - jak pisze Estreicher, uczestniczył w kompletowaniu prac potwierdzających kompetencje literackie i naukowe Pola, a także w staraniach o paszport ${ }^{26}$. Odjeżdżając 7 sierpnia do Wilna pod nieobecność Poźniaka w Mostkach, Pol żegnał się listem:

Mój kochany January! Nie spodziewałeś się, odjeżdżając, że mnie już nie zastaniesz, lecz dzięki Bogu, że się tak stało. Wiem, że przyjaźń twoja nie zmieni się dla mnie w oddaleniu, bo znam twe serce, kochany January! Dzięki ci tysięczne za to wszystko, coś kiedy dla mnie nieszczęśliwego przyjaciela uczynił, bądź pewien, iż nie zapomnę, czem dla mnie byłeś! Odjeżdżam, wiesz kogo zostawiam; wiesz wszystko, nie pozostaje mnie nic więcej, jak tylko prosić cię, żebyś za interesami Kornelii pochodził, starał się, żeby jej kapitał mógł być jak najprędzej ulokowany w Mostkach i był jej prawdziwym przyjacielem. Oto cię prosi twój Wincenty. Ja wyjeżdżam jednem słowem, na opatrzność boską — z łódką na morze! Będę do ciebie pisywał, lecz cokolwiek będzie, czy mnie się dobrze, czy źle powodzić będzie, zachowaj przed całym światem tajemnicę, jak gdybyś nic nie wiedział o tem, gdzie się obracam i co się ze mną dzieje. Piłata o to samo proszę w mym liście i ty uczyń to dla mnie. Jest to może ostatnia moja prośba, bo wiesz, jak ludzie wszystko nicują i jak się cieszyć zwykli cudzem nieszczęściem. Kornelia opowie ci wszystkie szczegóły o mnie. O Jagusi nic nie piszę, lecz wiesz czego ci życzę, dałby Bóg, żebyś nie napróżno

\footnotetext{
${ }^{25}$ K. Estreicher, Wincenty Pol..., s. 98.

${ }^{26}$ Tamże, s. 119, 121.
} 
jej pokój skłócił i był szczęśliwym! Bywaj mi zdrów, mój January! Daj Boże, żebyśmy się szczęśliwsi uścisnęli. Bądź zdrów i szczęśliwy! ${ }^{27}$

Małżeństwo Januarego Poźniaka z córką Józefa Ziętkiewicza, Agnieszką zawarte w 1838 r., na zawsze połączyło dwóch poetów - byli teraz nie tylko przyjaciółmi, ale i powinowatymi. Dowodów na nieprzemijające $\mathrm{z}$ biegiem czasu związki Pola i Poźniaka dostarcza wypowiedź K. Estreichera, który zwraca się do Poźniaka słowami:

Skoro poeta zawarł oczy, Ciebie jedynego powiernika zawezwałem. Stanąłeś do apelu. Wyświeciłeś mi całą przeszłość tak, jak pragnąłem tego. Co na zapomnienie było skazanem, wydobyłeś z pomroki niepamięci. Jedni uważać to będą za błachostkę, drudzy już dzisiaj będą nam obojgu wdzięczni, a tem bardziej dalsze pokolenie ${ }^{28}$.

Wyrazem przywiązania mimo zmian w życiu prywatnym są również wiersze dedykowane narzeczonej Pola - Kornelii Olszewskiej (po śmierci matki będącej nawet prawną podopieczną Poźniaka), nazywanej przez Poźniaka przyjaciółką. Żartobliwe świadectwo tej relacji zawierają wspomnienia K. Estreichera, piszącego:

Bywało, Wincenty udał się do Mostek i tam dłużej bawił, aniżeli przyobiecał. Panna zasępiała się, tęskniąc za nim, wówczas matka na poły żartując, mówiła jej: Wolałabyś kochać się w Januarym, bo ten, choć także lata po niebiosach, to jednak uczęszcza do szkoły i egzamina zdaje i będzie miał kawałek chleba, a twój Wincenty tylko buja i nic nie robi. Była to przymówka, aby Kornelia skłoniła Wincentego do ukończenia studyów, lecz ona tego nie wymagała, wolała kochać poetę niż prawnika ${ }^{29}$.

Poźniak w swoich wierszach - np. w cytowanej poniżej Gadce o kalinie dla panny Kornelii - kreśli metaforyczny obraz Kornelii, wykorzystując ludowe konotacje kaliny jako symbolu młodości i niewinności, symbolu bardzo chętnie wykorzystywanego w poezji romantycznej (np. u Lenartowicza czy Słowackiego):

$$
\begin{aligned}
& \text { Wzrosła kalina pośrodku dąbrowy, } \\
& \text { Strojna w prześliczny wianuszek liściowy; } \\
& \text { Między liściami tuliły się kwiaty, } \\
& \text { Ptaszkowie do niej przybywali w swaty... } \\
& \text { I przyleciało aż trzech ptaszków społem }{ }^{30} \text {. }
\end{aligned}
$$

\footnotetext{
27 Tamże, s. 122-123.

28 Tamże, s. 1-2.

29 Tamże, s. 101.

30 J. Poźniak, Pieśni..., s. 115.
} 
Nietrudno odgadnąć, że jednym z ptaków, które przyleciały do kaliny Kornelii, był Wincenty Pol - słowik ${ }^{31}$, ptak miłości:
Ptaszkowi, który bez zarozumienia
Usiadłszy w krzaczku, cudowne marzenia
Wcielać rozpoczął $w$ tren łzawy,
Kalina żadnej nie dała odprawy ${ }^{32}$.

Zgodnie z wierzeniami ludowymi utrwalonymi w literaturze i kulturze kalina i słowik, Kornelia i Wincenty, stanowią duet idealny. Z tego też powodu Poźniak może złożyć życzenia, również ubierając je w formę metafor bazujących na ludowej symbolice - wiersz Kornelii narzeczonej Wincentego:
A w nagrodę stałości, w nagrodę cierpienia,
Ziszczą ci się wiosenne o szczęściu marzenia:
Bujne kłosy okryją co rok waszą rolę,
Bocian gniazdo uwije na waszej stodole,
Pod niską wiejską strzechą zamieszka wesele,
Bóg ci drogę żywota - miłością wyściele ${ }^{33}$

Kilka miesięcy później Kornelia Olszewska - „już nie śliczne dziewczę, lecz z wypłakanym licem"34 - i Wincenty Pol się pobrali, a January Poźniak był drużbą na ich ślubie.

\section{Związki poetyckie}

Poźniak porównuje Pola nie tylko do orła i słowika, ale również do skowronka: Nasz skowronku! lotne ptaszę! / Po wysokiem bujasz niebie (...) Skowroneczku! ${ }^{35}$. Widzieć w tym skowronku należy - znowu przez pryzmat wierzeń ludowych - wiarę w moc poezji Pola. Skowronek zwiastuje wiosnę po mrocznej zimie, natomiast Pol wzywany jest:

${ }^{31}$ Słowikiem nazywa Poźniak także Mickiewicza: „Rzucasz nas - w mury Giedymina grodu, / co wychowały słowika narodu, pospieszasz", tamże, s. 65 .

${ }^{32}$ Tamże, s. 115.

${ }_{33}$ Tamże, s. 137.

${ }^{34}$ List Agnieszki Poźniakowej do Wincentego Hugona Pola (Juniora), w: Listy z ziemi naszej. Korespondencja Wincentego Pola z lat 1826-1872, oprac. Z. Sudolski, Warszawa 2004, s. 693.

${ }^{35}$ J. Poźniak, Pieśni..., s. 98. 


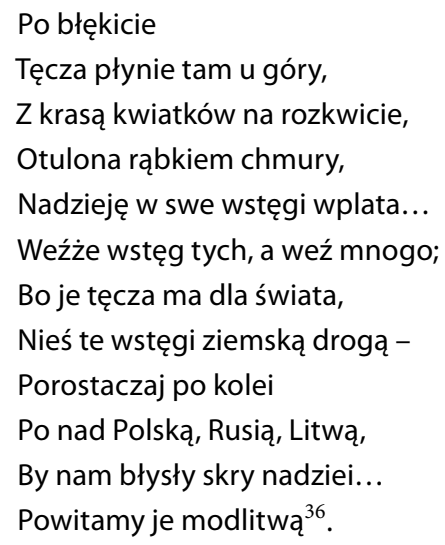

Nieprzemijające z czasem związki Poźniaka i Pola znajdują swój wyraz także w wierszu-życzeniu Wincentemu na imieniny:

\author{
Życzę, byś żył długie lata, \\ A na polskiej ziemi, \\ Wziętość, sławę miał u świata, \\ Miłość między swemi, \\ Doczekał się swobód kraju, \\ Nie zaznawszy wroga - \\ I po dawnym obyczaju, \\ Chwalił Pana Boga. \\ Nie miał tych trosk co za młodu, \\ A twa wieszcza dusza, \\ Żeby snuła dla narodu, \\ Te pieśni Janusza ${ }^{37}$.
}

Utwór Poźniaka datowany jest na 1835 r., a więc powstał wówczas, gdy w Paryżu ukazały się anonimowo Pieśni Janusza Wincentego Pola. To nie przypadek, że Poźniak posłużył się pseudonimem przyjaciela i sformułował takie właśnie życzenie. Jak bowiem świadczą zapiski Pola w dzienniku, Poźniak często był pierwszym czytelnikiem nowo powstałych utworów, np.: „Dzisiaj skończyłem mego Samobójcę. January powiada, że mi się udał”38.

Jak się okazuje w trakcie lektury wierszy Poźniaka, Pol był nie tylko przyjacielem, ale i wyznawcą tych samych ideałów, a nawet promotorem działań

\footnotetext{
36 Tamże.

37 Tamże, s. 127-128.

38 K. Estreicher, Wincenty Pol..., s. 100.
} 
poetyckich. Jak pisze Poźniak w przypisie do Pana Podstolego, „wiersz ten napisałem na wezwanie i wedle pomysłu Wincentego Pola"39.

Wincenty Pol przywoływany w utworach Poźniaka to również poeta najwyższej miary, wieszcz. W utworze Wspomnienia $z$ życia bieszczadzki poeta pisał:

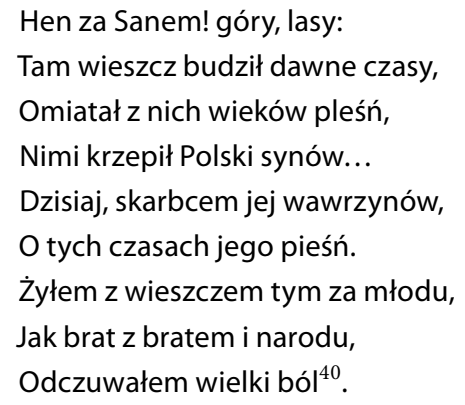

Poźniak niejednokrotnie wskazywał też wspólnotę myśli i ideałów z Polem i czas wspólnie spędzany w młodości. W utworze Po upływie pół wieku prawie, znów wiersz do Wincentego Pola ubolewał:

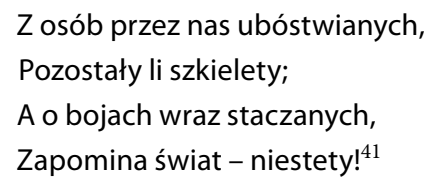

Troskę Pola o losy Polski wspomina również Estreicher, potwierdzając przy okazji uczucia łączące Pola z Poźniakiem:

Kiedy się rozpatruję w paśmie niepowodzeń i trosk żywota, jakoś mnie smutek ogarnia, że jemu nie było tak dobrze, jak sobie zasłużył, że marniał i zmarniał dlatego tylko, że miał serce wielkie, i że tak miłował kraj swój, jak miłował Kornelią i Ciebie January! ${ }^{42}$

Niezwykle chętnie Poźniak sięgał po motywy historyczne, co również łączyło go ze starszym przyjacielem. Opisywał Stefana Batorego, Bartłomieja Tura Zawadę, Józefa Bukowskiego, Bolesława Chrobrego czy pojedyncze wydarzenia z historii, np. rabację galicyjską. Warto się zatrzymać przy Wuku Karadziczu, którego zdaniem K. Estreicher, niejako za sprawą Poźniaka poznał także Pol:

\footnotetext{
39 J. Poźniak, Pieśni..., s. 87.

40 Tamże, s. 371.

41 Tamże, s. 276.

42 K. Estreicher, Wincenty Pol..., s. 3.
} 
Wagilewicz, Rusin, zaprzyjaźnił się przed r. 1828 z Januarym Poźniakiem, nauczył go kirylicy i grażdanki. Z Polem zaznajomił się dopiero po r. 1831. Nauka Wagilewicza nie poszła w las, Poźniak w kompanii z Wincentym zajęli się w roku 1828 czytaniem w oryginale pieśni ludowych serbskich, ze zbioru Stefana Wuka Karadzicza, które zapaliły wyobraźnię Pola, nawiodły na drogę tworzenia pieśni ludowych i zbierania ich, czem zajmował się w r. $1829^{43}$.

Serbskiemu leksykografowi i etnografowi Poźniak poświęcił wiersz Do Wuka Stefanowicza Karadzicza - za sprawą rytmu $8+6$ i powtórzeń stylizowany na pieśńn ${ }^{44}$ :

\author{
Hej gęślarzu! Z nad Dunaju! \\ Twe pieśni, twe pieśni: \\ Budzą przyszłość twego kraju \\ Co w pleśni, co w pleśni \\ Wieków, drzymie na Kossowym \\ Rozłogu, rozłogu - (...) \\ Siejże piewco! siej pieśniami \\ Po ziemi, po ziemi... \\ Niech im Bóg da wzejść czynami \\ Chrobremi, chrobremi ${ }^{45}$.
}

Tym, co łączy w opinii Poźniaka obu poetów, jest także nieuchronność śmierci:

Czas, co ciągle zanik sieje,

Zawezwie nas wkrótce obu;

Bo skończone nasze dzieje -

By położyć się do grobu ${ }^{46}$.

Warto przy tej okazji zauważyć powracający w utworach Poźniaka motyw zapomnienia i deprecjonowania własnej twórczości poetyckiej, zwłaszcza w konfrontacji z osiągnięciami Wincentego Pola. Co ciekawe, jak twierdzi K. Estreicher:

January poznał wyższość talentu Wincentego i odwodził go od karyery urzędniczej, skłaniając ku zawodowi literackiemu. Że go zrozumiał od razu i od razu oddawał mu cześć jako poecie, jeszcze w czasach gdy nie dało się przewidzieć, do czego doprowadzi marzycielstwo młodzieńca ${ }^{47}$.

\footnotetext{
${ }^{43}$ K. Estreicher, Wincenty Pol..., s. 76.

${ }_{44}$ Por. Z. Kopczyńska, L. Pszczołowska, Znaczenie i wartość form wierszowych $w$ kontekście literackim epoki (poezja polskiego baroku), „Pamiętnik Literacki”, 1969, z. 3, s. 206.

45 J. Poźniak, Pieśni..., s. 28-29.

${ }^{46}$ J. Poźniak, Pieśni..., s. 276.

${ }^{47}$ K. Estreicher, Wincenty Pol..., s. 104.
} 
Dowód wiary w poetycki talent Pola Poźniak daje w wierszu z 1829 r.:

Więc samą piosnkę, smutną jak Karpaty,

Dostaniesz w datku, pieśni świat nie klaśnie,

Lecz wiem, pieśń druha w twej duszy nie zgaśnie,

Jak pieśń Litwina w krainie Sarmaty! ${ }^{48}$

O sobie po latach Poźniak pisze:
Na mogiłę mą, kolumny
Nie pragnę, ale do trumny
Wieniec ów zabrać bym rad -
By mi przypominał w grobie:
Świat kochałeś, choć o tobie
Zapomniał - od wielu lat ${ }^{49}$,

a także $\mathrm{w}$ wierszu napisanym już po śmierci Pola:
Hej, mój druhu! Wieszczu stary!
Ty na straży naszej wiary
Stoisz, choć wstąpiłeś w grób;
Bo przetrwa tam pieśń twa wieki ${ }^{50}$,
Gdzie w graniczne biło rzeki,
Żelazny za słupem słup. ${ }^{51}$

\section{U Poźniaka odnaleźć można również wypowiedź wprost zestawiającą go z przy- jacielem poetą:}

Po mnie nic nie pozostanie -

Twoje pieśni i wołania,

48 Tamże, s. 105.

49 J. Poźniak, Pieśni..., s. 372.

50 W gorzkim tonie o pamięci o Polu wypowiadał się K. Estreicher: „Lecz czy on jest poetą? Czy jest narodowym?... Za takiego miano go za życia. Ledwo opuścił nas, aliści jedni jednego, drudzy drugiego zaprzeczyli mu przymiotu. A jednakowoż Polska może zdobędzie się kiedyś na drugiego Słowackiego, ale drugiego Pola już mieć nie będzie. W nim i z nim ginie świat , który oglądał i który opiewał. Polska będzie przez długie lata uczyć się na pamięć Pieśni o ziemi naszej, choć ją chłodny krytyk nazwał rymowaną geografią. I choćby z katedry urzędownie odmówiono mu patentu na poetę, kraj cały będzie po Panu Tadeuszu czytać Mohorta” (K. Estreicher, Wincenty Pol..., s. 7-8).

51 J. Poźniak, Pieśni..., s. 371. 
Nie przebrzmią na polskim łanie,

Nawet po dniu - zmartwychwstania ${ }^{52}$,

dodajmy, że to fragment wiersza datowanego na 5. kwietnia 1872 r. - Pol umrze w grudniu tego samego roku i fakt ten nie wywoła poetyckiej reakcji Poźniaka. Wątek Pola powróci dopiero we Wspomnieniu z życia z $1882 \mathrm{r}$.

Pol określany mianem wieszcza jest niejednokrotnie w twórczości Poźniaka - często rzeczownikowi towarzyszy dookreślenie wskazujące na doświadczenie: wieszczu stary ${ }^{53}$ i wspólnotowość: nasz wieszcz $z^{54}$. Warto pamiętać jednak, że leksem oznaczał wówczas 'człowieka natchnionego przepowiadającego przyszłość; poetę genjalnego, śpiewaka, lirnika, gęślarza jasnowidzącego ${ }^{55}$. Wieszcz w poezji Poźniaka ma jeszcze jedno zadanie: ocalić pamięć o przeszłości i mobilizować do walki o niepodległość:
Nasi wieszcze, pieśni cudem,
Krzewią wiarę w zmartwychwstanie
Pomiędzy tym polskim ludem,
Niosą mu mir i kochanie -
A proroczem namaszczeniem,
Tak go chronią przed zwątpieniem,
Jako twierdze mur ${ }^{56}$.

W przywoływanym już wierszu dla odjeżdżającego do Wilna przyjaciela pada również stwierdzenie o geniuszu ${ }^{57}$ Pola:
Rzucasz nas - w mury Giedymina grodu,
Co wychowały słowika narodu,
Pospieszasz z zdobyczą twą;
Żeby umysły litewskiej młodzieży,
Która w zbawienność prac duchowych wierzy,
Geniuszu krzepić skrą ${ }^{58}$.

W przywołanych wypowiedziach Poźniaka wyraźnie widać emocjonalność budowaną z operowaniem zaimkami osobowymi. Gdy mówi o wspólnej prze-

\footnotetext{
${ }^{52}$ Tamże, s. 277.

${ }_{53}$ Tamże, s. 371.

54 Tamże, s. V.

${ }^{55}$ SWar, t. 7, s. 593.

${ }_{56}$ J. Poźniak, Pieśni..., s. 134.

${ }^{57}$ geniusz 'umysł wyższy nad pospolite umysły', SWil, s. 341.

58 J. Poźniak, Pieśni..., s. 65.
} 
szłości bądź nieuchronnej przyszłości - śmierci - posługuje się zaimkiem my, natomiast gdy odnosi się do pamięci o sobie i Polu, zawsze rozgranicza ja i ty; ja - gorszy, ty - najlepszy poeta, wieszcz.

W świetle badań stylistycznych trudno uznać pewność własnego zapomnienia za jedynie fałszywą skromność czy kokieterię Poźniaka. Rzeczywiście był poetą przeciętnym, $z$ trudem panującym nad rytmicznym tokiem wypowiedzi, nad spójnością wywodu, choć dbającym o utrzymanie rytmu wiersza - chętnie wybierał popularne metra, tj. 6-, 8- i 13-zgłoskowe, a także układy mieszane 8+6 i $11+13$. Trudno też przyznać mu klasę w posługiwaniu się środkami poetyckiego wyrazu, m.in. metaforami, porównaniami czy epitetami, np.:

\author{
Chwile z tobą spędzone \\ słodsze niźli miód pszczółki \\ Budzą szczęście uśpione \\ Jako wiosnę jaskółki. \\ Gdy już dadzą mi ciebie, \\ Jak skowronek na wiosnę \\ Będę bujał po niebie, \\ Dzwonił pieśni radosne ${ }^{59}$ (Będziesz moja).
}

Czy do Poźniaka także można odnieść recenzję Estreichera, konfrontującego potencjał poetycki Pola i innych poetów:

Do przystrojenia pieśni wybrał [Pol] wiersz najprostszy, płynący szparko, gładziuchno, jakby stworzony pod nutę. Skojarzenie formy z treścią w ten sposób utworzyło pieśń prostą na pozór, niby łatwą do wygłoszenia a nie podobną do naśladowania. Ktokolwiek próbował pójść w ślady Pola upadał, bo nie znał jego tajemnicy uroku ${ }^{60}$ ?

Zastanawiać się można, dlaczego Wincenty Pol - jak wynika z przywołanej już obudowy tekstu Pana Podstolego Poźniaka - zachęcał go do pisania. Estreicher cytuje inny wiersz napisany przez Poźniaka na „zlecenie” Pola z komentarzem:

Bywał tam [u Kopystyńskich] i January Poźniak, ale już nie umiał tak zjednywać sobie życzliwości zardzewiałego szlachcica. Odwetował się za to na nim pan January, wykoncypowawszy wiersz na wezwanie Pola i według jego instrukcyi, w którym odmalował stosunek obojga małżeństwa ${ }^{61}$.

\footnotetext{
59 J. Poźniak, Pieśni..., s. 16.

${ }^{60}$ K. Estreicher, Wincenty Pol..., s. 19.

${ }^{61}$ Tamże, s. 63.
} 
Czy Pol doradzał pisanie z przyjacielskiej życzliwości, czy też może Poźniak jako młodzieniec sprawniej posługiwał się piórem i wykazywał zdolności poetyckie, których jednak z biegiem czasu nie rozwinął? Trudno o tym wyrokować. January Poźniak, mimo poetyckich planów na życie, w 1835 r. w wierszu Wincentemu na imieniny składał samokrytykę:

Życzenia, upominki, niosą ci dziś w dance,

Ja ślę akord tej gęśli, co u mnie rdzewieje,

Na której brząknę czasem, gdy serce boleje ${ }^{62}$.

O tej samej gęśli wspomina w 1882 r. w przedmowie do Pieśni z lat młodych i pieśni starca:

[...] piszę o sobie, żeby uprzedzić, że struny na mojej gęśli dawno pordzewiały - nie z mej przewiny - niechże [czytelnik] pobłażliwie ocenia zawarte w książce tej me pieśni ${ }^{63}$

i w wierszach z lat 1873-1874 - Dla czego nie śpiewam:

i Do mojej geśli:
Jam gęślarzem był za młodu -
I bywało gęśli struny,
W mojej dłoni w cześć narodu
Grzmiały czasem, jak pioruny.
Żyć gęślarzem los mi wzbronił,
Choć tkwi w duszy pieśni wdzięk -
I chętnie bym pieśń zadzwonił,
Lecz z strun gęśli płynie jęk... ${ }^{64}$,

Gęśli moja! zapylona,

Zardzewiała, rozstrojona

Milczałaś dziesiątki lat ${ }^{65}$.

Jak pisze Aleksander Zyga, „w swoich niezbyt wysoko pod względem artystycznym stojących wierszach był (...) [Poźniak] pojętnym uczniem gawędowej i pejzażowej poezji W. Pola oraz korzystającego z ludowej pieśni ukraińskiej

\footnotetext{
62 J. Poźniak, Pieśni..., s. 127.

63 Tamże, s. IX.

64 Tamże, s. 277-278.

65 Tamże, s. 278.
} 
Józefa Bohdana Zaleskiego" ${ }^{\text {66 }}$. Wpływy Pola - zwłaszcza w wierszach opisujących Sanok i okolice - są nie do ukrycia, por. Beskid:

\author{
Hej, Beskidzie! Tyś bogaty: \\ W wonne zioła, w śliczne kwiaty, \\ Nad wyniosłem twojem czołem, \\ Krążą orzeł ze sokołem; \\ U stóp twoich szumi San. \\ Masz cieniste gaje, lasy, \\ Połoniny pełne krasy, \\ Pola orne, sioła ludne \\ I dąbrowy te przecudne, \\ Jakby możny polski pan ${ }^{67}$.
}

Zwraca tu uwagę onim Beskid, gdyż także w nim można widzieć oddziaływanie przyjaciela-poety. Jak bowiem stwierdził A. Zyga, to „Wincenty Pol (...) na oznaczenie dzisiejszego zakresu pojęcia Bieszczadów posługuje się nazwą Beskidu”68.

Wspomniane przez Zygę inspiracje Zaleskim odnaleźć można np. w Krzaku kalinowym na Czerwonej Rusi, jednym z udramatyzowanych utworów Poźniaka:
Pod Haliczem na rozłogu,
Pośród cierni, pośród głogu,
Wyrósł kalinowy krzak.
Na tym krzaku kalinowym,
Co to fruktem koralowym
Błyszczy, zwykł siadywać ptak -
I całemi godzinami,
Nad cierniami i głogami
Rozwodzić tej pieśni śpiew ${ }^{69}$.

Gdyby nie wierność motywom bieszczadzkim January Poźniak zapewne zostałby poetą nieznanym, wspominanym jedynie w kontekście przyjaciół

${ }^{66}$ Poźniak January [hasło], w: Polski słownik biograficzny, t. 28, Wrocław-Warszawa 1984, s. 312. Por. nekrologi: „pieśń jego (...) pod względem formy niewykwintna”, „Dziennik Polski”, 1883, nr 82, „Poźniak miał talent poetycki , chociaż nie wyższej miary i niezdolny do potężniejszego polotu, ale nie bez wdzięku i pewnej oryginalności”, „Gazeta Lwowska”, 1883, nr 81.

${ }^{67}$ J. Poźniak, Pieśni..., s. 103; zob. A. Zyga, Bieszczady i Podkarpacie w rymotwórstwie, „Wierchy”, 1968, R. 37, s. 77.

${ }^{68}$ A. Zyga, Bieszczady i Podkarpacie..., s. 66.

${ }^{69}$ J. Poźniak, Pieśni..., s. 288-289. 
i naśladowców Pola, jak o nim piszą kronikarze ${ }^{70}$, Aleksander Zyga ${ }^{71}$ czy Roman Kaleta $^{72}$. Jednak za sprawą kreślenia obrazów Sanoka i okolic zyskał miano piewcy Bieszczad i na trwałe zapisał się na kartach regionu -

choć był bardzo przeciętnym poetą i epigonem swojej epoki, na uwagę zasługują jego wiersze poświęcone Ziemi Sanockiej (...) Janusz Szuber zauważa, że Poźniak, „obok Wincentego Pola, Jana Kantego Podoleckiego, z którymi się przyjaźnił, i Zygmunta Kaczkowskiego dokonał dla nas, sanoczan, rzeczy ważnej - wprowadził ukochaną przez siebie, traktowaną w kategoriach arkadii Ziemię Sanocką do literatury doby romantyzmu i na miarę swoich umiejętności i możliwości wykreował ją jako uczestniczkę ówczesnych prądów myślowych i artystycznych ${ }^{73}$.

Można zaryzykować stwierdzenie, że dzisiaj jest tam bardziej znany i doceniany niż w przeszłości ${ }^{74}$. Otwarte pozostaje jednak pytanie, czy to zasługa walorów jego twórczości, czy wystarczający jest fakt opiewania Sanu i Karpat. Niewątpliwie jednak na jego poezji - i marzeniu o byciu poetą - swe piętno wycisnął Wincenty Pol, przyjaciel i wzorzec poetycki.

\section{Bibliografia}

Estreicher K., Wincenty Pol - jego młodość i otoczenie (1807-1832), Lwów 1882.

Kaleta R., Nie zginęła: dzieje recepcji "Mazurka Dąbrowskiego", "Pamiętnik Literacki”, 1988, 79/1, s. 193-264.

Kopczyńska Z., Pszczołowska L., Znaczenie i wartość form wierszowych w kontekście literackim epoki (poezja polskiego baroku), "Pamiętnik Literacki”, 1969, z. 3, s. 195-210.

Listy zziemi naszej. Korespondencja Wincentego Pola z lat 1826-1872, oprac. Z. Sudolski, Warszawa 2004. [Kronika] "Gazeta Lwowska”, 1883, nr 81.

[Kronika] „Dziennik Polski”, 1883, nr 82.

Poezja Januarego, "Tygodnik Sanocki”, 2008, 51/52 [online: http://tygodniksanocki.eu/archiwum/2008/nr51-52.pdf dostęp 20.04.2017]

Pol A., Estyma Wincentego Pola do króla Jana III Sobieskiego, „Komunikaty Mazursko-Warmińskie”, 2001, nr 1, s.67-76 [online: http://bazhum.muzhp.pl/media//files/Komunikaty_Mazursko_War-

${ }^{70}$ „W życiu śp. Wincentego Pola, January Poźniak odegrał ważną rolę jako przyjaciel, wielbiciel i protektor”, „Dziennik Polski”, 1883, nr 82.

${ }^{71}$ „Zastosowana przez Pola w jego geograficznych wierszach wspomnieniowa aura zaciążyła w sposób widoczny na jego naśladowcach, szczególnie na wierszach J. Poźniaka, których wiele poświęcił spędzonym w Bieszczadach chwilom”, A. Zyga, Bieszczady i Podkarpacie..., s. 76.

72 „zapomniany dziś poeta, przyjaciel Wincentego Pola”, R. Kaleta, Nie zginęła: dzieje recepcji „Mazurka Dąbrowskiego”, „Pamiętnik Literacki”, 1988, 79/1, s. 202.

${ }^{73}$ Poezja Januarego...

${ }^{74}$ „Lokalnych patriotów i miłośników literatury zachęcamy do zainteresowania się tomikiem Januarego Poźniaka, zapomnianego XIX-wiecznego galicyjskiego poety, piewcy Ziemi Sanockiej”, 2008. 
minskie/Komunikaty_Mazursko_Warminskie-r2001-t-n1/Komunikaty_Mazursko_Warminskie-r2001-t-n1-s67-76/Komunikaty_Mazursko_Warminskie-r2001-t-n1-s67-76.pdf dostęp 20.06.2017] Poźniak J., Pieśni z lat młodych i pieśni starca, Lwów 1883.

Poźniak January [hasło], w: Polski słownik biograficzny, t. 28, Wrocław-Warszawa 1984, s. 311-312. SWar - Słownikjęzyka polskiego, red. J. Karłowicz, A. Kryński, W. Niedźwiedzki, Warszawa 1900-1927. SWil - Słownik języka polskiego, red. A. Zdanowicz, M. Bohusz-Szyszka, J. Filipowicz, Wilno 1861 [online: https://eswil.ijp.pan.pl/ dostęp 20.04.2017]

Zyga A., Bieszczady i Podkarpacie w rymotwórstwie, „Wierchy”, 1968, R. 37, s. 64-95.

\section{Streszczenie}

Artykuł poświęcony jest omówieniu widocznych w poezji Januarego Poźniaka, związków z Wincentym Polem. Wiersze Poźniaka, lwowskiego prawnika i społecznika od wczesnej młodości marzącego o byciu poetą, są świadectwem wieloletniej przyjaźni z Polem i jego żoną, Kornelią. Poźniak pisze m.in. o wyjeździe Pola do Wilna czy wykorzystując symbolikę ludową, opisuje romans poety z Kornelią. Twórczość Poźniaka ujawnia także wspólną obu poetom troskę o losy narodu, a także wiarę w nieprzemijalność sławy Pola. Fascynacja Polem - poetą i wieszczem - przejawia się nie tylko poprzez stosowaną przez Poźniaka leksykę, ale również poprzez nawiązania do jego poetyki przy jednoczesnym deprecjonowaniu własnych dokonań literackich (motyw zapomnienia i „rdzewiejącej gęśli”).

Słowa klucze: poezja, biografia, romantyzm, inspiracje.

\section{„Żyłem z wieszczem tym za młodu, jak brat z bratem..." \\ - social and poetic links between January Poźniak \\ and Wincenty Pol}

\section{summary}

This article discusses noticeable links between January Poźniak and Wincenty Pol as revealed in the poetry of the former. Poźniak's poetic oeuvre - a Lviv lawyer and social activist, who always dreamt of becoming a poet - is an evident testimony of his lifelong friendship with Pol and his wife Kornelia. Poźniak touches upon such issues like Pol's departure to Vilnius or his romantic affair with Kornelia - embedded in a folk symbolic framework. Poźniak's works also reveal that both authors shared their sentiment for the fate of the nation. They also unveil Poźniak's strong belief in Pole's everlasting fame. Poźniak's fascination with Pol - a poet and a national prophet - presents itself through his choice of vocabulary and his references to Pol's poetic conventions, accompanied with a tendency to depreciate Poźniak's own literary achievements (cf. motives of oblivion and the "rusty gusle").

Keywords: poetry, biography, Romanticism, inspirations. 